\title{
YXQ-EQ Induces Apoptosis and Inhibits Signaling Pathways Important for Metastasis in Non-Small Cell Lung Carcinoma Cells
}

\author{
Xin Yan ${ }^{a, b}$ Hua Shen ${ }^{b}$ Hongjian Jiang ${ }^{c}$ Dan Hud Jun Wang ${ }^{d} \quad$ Xinqi Wu \\ ${ }^{a}$ Chongqing Institute of Traditional Chinese Medicine, Chongqing, China, ${ }^{b} N e w$ Medical Science \\ Research Institute, New York, 'Cardiovascular Clinical Science Foundation, Boston, dBrigham and \\ Women's Hospital and Harvard Medical School, Boston, eDana-Farber Cancer Institute and Harvard \\ Medical School, Boston, USA
}

\section{Key Words}

NSCLC • Apoptosis • Migration • Invasion • EMT • EGF • TGF- $\beta \cdot \mathrm{YXQ}-\mathrm{EQ}$

\begin{abstract}
Background/Aims: Lung cancer is one of the most prevalent malignancies in the world. The 5 -year survival rate for non-small cell lung cancer (NSCLC) patients is only approximately $15 \%$, with metastasis as the primary cause of death. This study was aimed to investigate cytotoxic effect of external qi of Yan Xin Qigong (YXQ-EQ) toward human lung adenocarcinoma A549 cells as well as its effect on signaling pathways promoting migration, invasion and epithelial-to-mesenchymal transition (EMT) in A549 cells. Methods: Cytotoxic effect of YXQEQ was evaluated using MTS [3-(4,5-dimethylthiazol-2-yl)-5-(3-carboxymethoxyphenyl)-2(4-sulfophenyl)-2H-tetrazolium, inner salt] and cologenic assays. Apoptosis of treated cells was determined by Annexin V/propidium iodide staining and flow cytometry analysis, while cell migration and invasion were determined using transwell assays and EMT was assessed by morphological changes in cells. Protein expression and phosphorylation were examined by immunoblot analyses. Results: YXQ-EQ induced apoptosis in A549 cells, resulting in a pronounced reduction in viability and clonogenic formation. This was associated with inhibition of phosphorylation of AKT and ERK1/2 and reduced expression of anti-apoptotic proteins $B C L-X L, X I A P$ and survivin. Furthermore, $Y X Q-E Q$ inhibited EGF/EGFR signaling and EGF mediated migration and invasion of $A 549$ cells. While TGF- $\beta 1$ induced phosphorylation of SMAD2/3 and EMT in A549 cells, YXQ-EQ suppressed TGF- $\beta / S M A D$ signaling and induced cell death in these cells in the presence of TGF- $\beta 1$. Conclusion: Our findings suggest that YXQ-EQ could exert anti-lung cancer effects via inhibiting signaling pathways that are important for NSCLC cell survival and NSCLC metastasis.




\section{Cellular Physiology Cell Physiol Biochem 2018;49:911-919 $\begin{array}{ll}\text { DOI: 10.1159/000493223 } & \text { O } 2018 \text { The Author(s). Published by S. Karger AG, Basel } \\ \text { and Biochemistry } & \text { Published online: } 5 \text { September, } 2018 \text { www.karger.com/cpb }\end{array}$ \\ Yan et al.: YXQ-EQ Induces Apoptosis and Inhibits Pro-Metastatic Pathways in NSCLC \\ Cells}

\section{Introduction}

Lung cancer is the most common malignant disease and the leading cause of cancer related mortality worldwide [1]. Non-small cell lung cancer (NSCLC) comprises the majority of lung cancer cases, with most NSCLC patients having advanced stage disease at diagnosis [2]. The 5-year survival rate for NSCLC patients is only approximately $15 \%$, with metastasis as the primary cause of death [3]. Conventional standard of care therapies for metastatic NSCLC include chemotherapy, targeted therapy and immunotherapy [4]. However, clinical efficacy of these therapies is limited by the development of intrinsic or acquired drug resistance [5]. Novel approaches are therefore needed for effective treatment of NSCLC.

External Qi therapy of traditional Chinese medicine (TCM) has long been one of the medical practices in China and managed by the Chinese health authorities [6]. The concept of External Qi (of Qigong) refers to the technology and ability of "Qi deployment" therapy and health preservation of TCM [6-11]. Clinical observations over the past 30 years and ongoing studies have documented significant beneficial effects of external Qi of Yan Xin Qigong (YXQEQ) on patients with cancer and other diseases [12-16]. Studies over the past three decades have demonstrated influence of YXQ-EQ on both the structural and functional properties of biomolecules [17-22]. Furthermore, YXQ-EQ has been shown to induce apoptosis in cancer cells while protect neurons from oxidative stress induced cell death via modulating signaling pathways and gene expression [6-11,23]. These studies provide some molecular and cellular insights into the observed clinical benefits of YXQ-EQ.

We have previously shown that YXQ-EQ induces apoptosis and alters the expression of multiple genes involved in cell migration and energy metabolism in small cell lung cancer (SCLC) cells [10]. In the present study, we examined the effect of YXQ-EQ on NSCLC A549 cells. We report that YXQ-EQ exerted potent cytotoxic effect on A549 cells and inhibited EGF/ EGFR and TGF- $\beta$ /SMAD signaling that are important for NSCLC metastasis.

\section{Materials and Methods}

\section{Cell culture}

Human lung adenocarcinoma A549 cells (ATCC, Manassas, VA) were cultured in DMEM containing $10 \% \mathrm{FBS}, 50 \mu \mathrm{g} / \mathrm{ml}$ penicillin and $100 \mu \mathrm{g} / \mathrm{ml}$ streptomycin. For EGF and TGF- $\beta$ signaling studies, A549 cells were serum starved overnight and treated with EGF $(10 \mathrm{ng} / \mathrm{ml})$ or TGF- $\beta 1(10 \mathrm{ng} / \mathrm{ml})$ for $15 \mathrm{~min}$ and then harvested for immunoblot analyses.

\section{Viability assay}

Cell viability assay was performed as previously described [7, 8]. Briefly, cells were plated in 96well plates at $2 \times 10^{3}$ cells/well and incubated overnight prior to treatment with YXQ-EQ for 5 min. Cell viability was determined using an MTS [3-(4, 5-dimethylthiazol-2-yl)-5-(3-carboxymethoxyphenyl)-2-(4sulfophenyl)-2H-tetrazolium, inner salt] assay with a CellTiter 96 Aqueous One Solution Cell Proliferation Assay kit (Promega, Madison, WI).

\section{Clonogenic assay}

Clonogenic assay was performed as previously described $[9,11]$. Briefly, A549 cells were suspended in growth medium and plated in 6-well plates at $1 \times 10^{3}$ cells/well. Medium was changed every 3 - 4 days. Following two weeks after YXQ-EQ treatment, colonies were fixed with methanol, stained with crystal violet and counted. 


\section{Cellular Physiology Cell Physiol Biochem 2018;49:911-919 \begin{tabular}{ll|l} 
and Biochemistry & Publisned online: 5 september, 2018 & (c) 2018 The Author(s). Published by S. Karger AG, Basel \\
wwarger.com/cpb
\end{tabular} \\ Yan et al.: YXQ-EQ Induces Apoptosis and Inhibits Pro-Metastatic Pathways in NSCLC \\ Cells}

\section{Apoptosis analysis}

Cell apoptosis was analyzed as previously described [9]. Briefly, cells were collected after trypsinization and incubated in Annexin V binding buffer containing FITC-Annexin V (BD Bioscience, San Jose, CA) and propidium iodide (PI) for $15 \mathrm{~min}$. Stained cells were subjected to flow cytometric analysis and cell apoptosis was assessed using Flowjo.

\section{Migration and invasion assay}

Cell migration and invasion assay was performed in Transwell Boyden chambers and chambers coated with Matrigel as described previously [9]. Overnight serum starved A549 cells in DMEM containing 0.1\% BSA were added to the inserts. The lower chambers were supplemented with $600 \mu \mathrm{l}$ of DMEM containing $0.1 \%$ BSA with or without EGF $(25 \mathrm{ng} / \mathrm{ml}$ ). After incubation for $16 \mathrm{~h}$, cells that did not migrate were carefully wiped off. Migrated cells were fixed with methanol, stained with crystal violet, and counted in 4 randomly selected fields then averaged.

\section{Immunoblot analysis}

Whole cell lysates were prepared and proteins of interest were detected by immunoblot analyses as described previously $[9,11]$. Antibodies recognizing the following proteins were sourced from Cell Signaling Technology (Danvers, MA): AKT (catalog \#9272), pAKT (Ser473, catalog \#4060), ERK1/2 (catalog \#4695), pERK1/2 (Thr202/Tyr204, catalog \#4370), BCL-xL (catalog \#2764), XIAP (catalog \#2042), survivin (catalog \#2808), PARP (catalog \#9542), casapase-3 (catalog \#9662), SMAD2/3 (catalog \#8685), pSMAD2 (Ser465/467, catalog \#3108), pSMAD3 (Ser423/425, catalog \#9520). Other antibodies included EGFR (catalog \#A300-388A, Bethyl Laboratories, Montgomery, TX), pEGFR (Tyr1068, catalog \#44788G, Invitrogen, Grand Island, NY), and actin (catalog \#A2228, Sigma-Aldrich, St. Louis, MI).

\section{EMT induction}

A549 cells were treated with TGF- $\beta 1(10 \mathrm{ng} / \mathrm{ml})$ for $48 \mathrm{~h}$ in growth medium to induce EMT. Morphological changes of cells were observed under an inverted microscope.

\section{Statistical analysis}

Data are presented as mean \pm SD. Statistical significance was determined using two-tailed Student's $t$-test. $P<0.05$ was considered significant.

\section{Results}

$Y X Q-E Q$ exerts potent cytotoxic effect on $A 549$ cells

To examine any cytotoxic effect of YXQ-EQ, A549 cells were treated with YXQEQ for $5 \mathrm{~min}$ and cell viability was determined using an MTS assay $24 \mathrm{~h}$ later. YXQ-EQ treatment resulted in pronounced reduction (by approximately 93\%) in cell viability (Fig. 1A). Furthermore, YXQ-EQ treated A549 cells failed to form colonies in contrast to the many colonies that developed from control untreated A549 cells (Fig. 1B). These findings demonstrated a potent cytotoxic effect of YXQ-EQ on A549 cells.

Fig. 1. YXQ-EQ reduced A549 cell viability and colony formation. A549 cells were treated or not with YXQ-EQ for $5 \mathrm{~min}$. A. Cell viability was determined at $24 \mathrm{~h}$ after the treatment. Results are presented as mean \pm SD of percent viability from 3 independent experiments. ${ }^{*} P<0.01$, versus control cells. B. Colonies were stained and photographed 2 weeks after the treatment. Representative images from 3 independent experiments with similar results are shown.

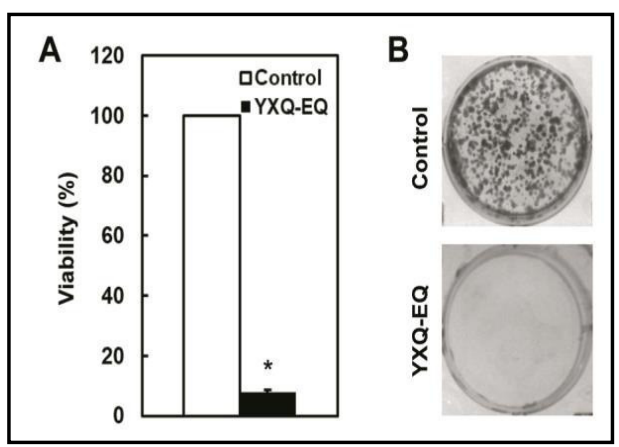


Fig. 2. YXQ-EQ induced apoptosis in A549 cells. A. YXQ-EQ inhibited phosphorylation of AKT (Ser473) and ERK1/2. B. YXQ-EQ reduced the expression of survivin, BCL-xL and XIAP. $C$ and D. Cells were stained with Annexin V-FITC and PI and analyzed by flow cytometry. Representative results are shown in $\mathrm{C}$ and the mean $\pm \mathrm{SD}$ of percent apoptotic cells from 3 independent experiments are presented in D. ${ }^{*} P<$ 0.01 , versus control cells. E. Immunoblot analysis of PARP and pro-caspase-3 cleavage. Cells were treated with YXQEQ for $5 \mathrm{~min}$ and collected $16 \mathrm{~h}$ and $20 \mathrm{~h}$ post treatment respectively for immunoblot analyses and Annexin V/PI staining.

Fig. 3. YXQ-EQ inhibited EGF/EGFR signaling in A549 cells. Serum starved A549 cells were treated or not with YXQ-EQ for $5 \mathrm{~min}$ and then stimulated with EGF. A. YXQ-EQ inhibited EGF induced EGFR activation. Control and YXQ-EQ treated cells were stimulated with or without EGF for $15 \mathrm{~min}$ and subjected to immunoblot analysis of phosphorylation of EGFR, AKT (Ser473), and ERK1/2. B and C. YXQEQ inhibited EGF induced A549 cell migration. D and E. YXQ-EQ inhibited EGF induced A549 cell invasion. Migration and invasion of A549 cells were induced with EGF for $16 \mathrm{~h}$.
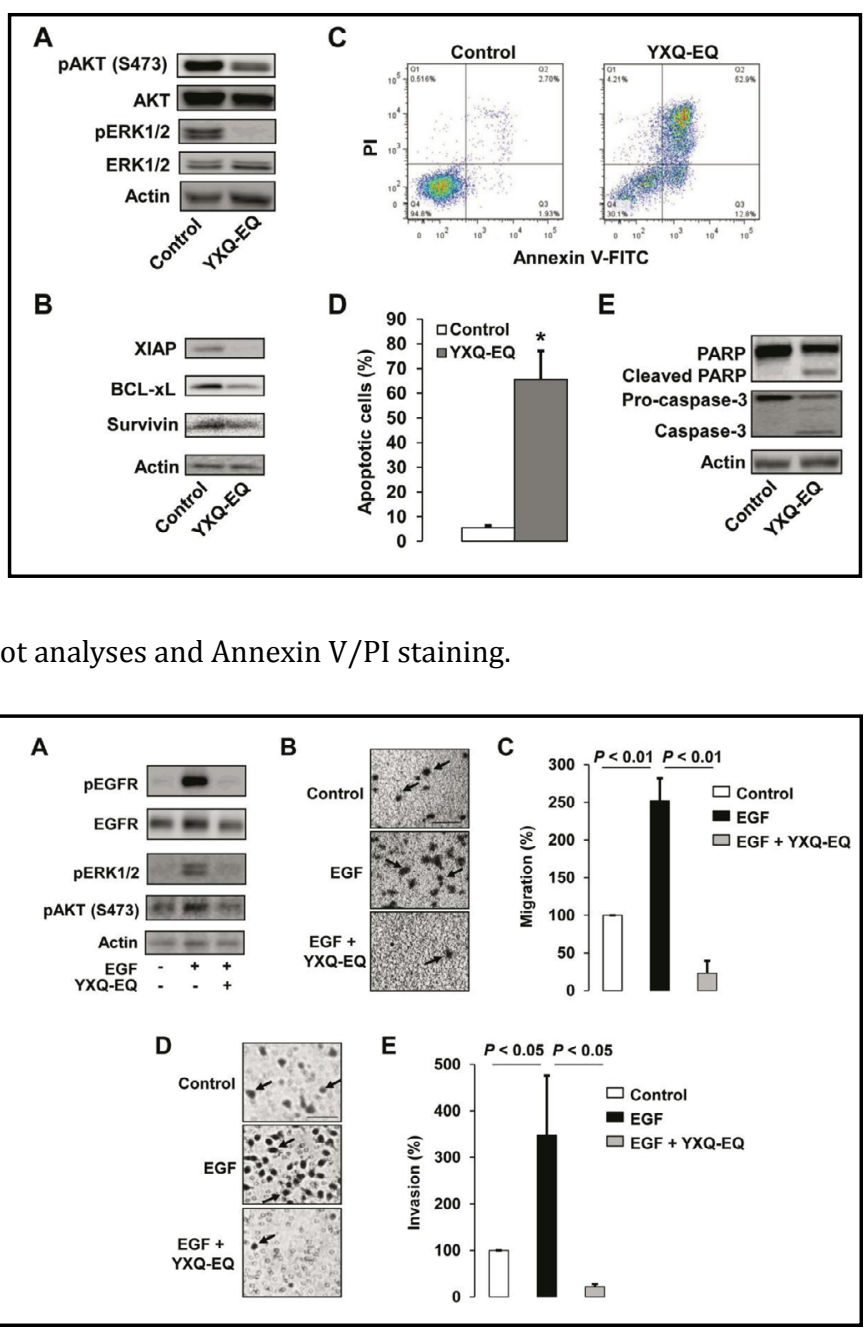

Migrated cells were fixed, stained, photographed and counted. Representative images (B and D) and the mean \pm SD of percent migration (C) and invasion (E) from 3 independent experiments are shown. Arrows indicate migrated cells in panels B and D. Scale bar, 200 pixels.

\section{YXQ-EQ induces apoptosis in A549 cells}

To better understand the cytotoxic effect of YXQ-EQ on A549 cells, we next examined if YXQ-EQ influenced the PI3K/AKT and MAPK/ERK1/2 pathways that are known to be critical for A549 cell survival [24]. Immunoblot analyses revealed significant suppression of phosphorylation of AKT (Ser473) and ERK1/2 in YXQ-EQ treated A549 cells (Fig. 2A). Furthermore, the expression of anti-apoptotic proteins BCL-XL, survivin and XIAP was reduced in YXQ-EQ treated A549 cells (Fig. 2B). We next investigated if YXQ-EQ exerted its cytotoxic effect by inducing apoptosis in A549 cells. Apoptosis was measured using Annexin V-FITC/PI staining and flow cytometric analysis $20 \mathrm{~h}$ after YXQ-EQ treatment. Apoptotic cells consist of Annexin V positive/PI negative early apoptotic cells and Annexin V positive/ PI positive late apoptotic cells. A small fraction (approximately 5\%) of apoptotic cells were detected in control untreated A549 cells (Fig. 2C and D). However, approximately 65\% of the YXQ-EQ treated A549 cells underwent apoptosis (Fig. 2C and D). Apoptosis in YXQ-EQ treated A549 cells was further confirmed by the cleavage of pro-caspase-3 and PARP as revealed by immunoblot analyses (Fig. 2E). 
Yan et al.: YXQ-EQ Induces Apoptosis and Inhibits Pro-Metastatic Pathways in NSCLC

Cells

Fig. 4. YXQ-EQ inhibited TGF- $\beta /$ SMAD signaling in A549 cells. A. YXQ-EQ reduced SMAD2/3 protein expression and phosphorylation. Cells were treated with YXQ-EQ for 5 min, collected and lysed for immunoblot analyses $16 \mathrm{~h}$ later. B. YXQ-EQ suppressed TGF- $\beta 1$ stimulated SMAD2/3 phosphorylation. Serum starved A549 cells were treated or not with YXQ-EQ for $5 \mathrm{~min}$ then treated with TGF- $\beta 1$ for $15 \mathrm{~min}$. C and D. A549 cells alone (C) underwent EMT

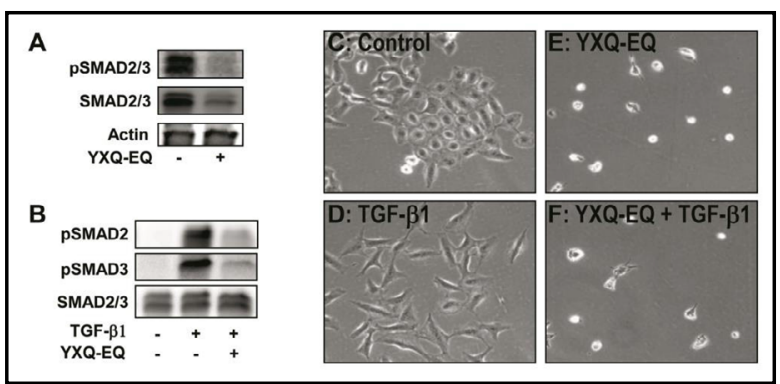

A

after $48 \mathrm{~h}$ of TGF- $\beta 1$ treatment (D). E and F. YXQ-EQ treated A549 cells lost intact morphology and died either in the absence (E) or presence (F) of TGF- $\beta 148 \mathrm{~h}$ after YXQ-EQ treatment. For co-treatment, cells were incubated with TGF- $\beta 1$ following 5 min of YXQ-EQ treatment.

\section{YXQ-EQ inhibits EGF/EGFR mediated A549 cell migration and invasion}

EGFR is known to be overactive in lung cancer cells due to overexpression or gain-offunction mutations [25-27]. The binding of EGFR with its ligands activates several signaling cascades important for lung cancer cells, principally the RAS/RAF/MEK/ERK pathway and the PI3K/AKT pathway [28, 29]. To investigate if YXQ-EQ influenced EGFR signaling in A549 cells, we examined the effect of YXQ-EQ on EGF/EGFR mediated AKT and ERK1/2 activation. As expected, treatment of A549 cells with EGF only increased phosphorylation of EGFR and downstream effectors AKT (Ser473) and ERK1/2 (Fig. 3A). Furthermore, EGF treatment alone promoted A549 cell migration and invasion (Fig. 3B-E). Treatment of A549 cells with YXQ-EQ for 5 min prior to EGF incubation abrogated EGF stimulated phosphorylation of EGFR (Tyr1068), AKT (Ser473) and ERK1/2 (Fig. 3A). YXQ-EQ treatment prior to EGF incubation not only completely inhibited EGF induced migration (Fig. 3B and C) and invasion (Fig. 3D and E) but also significantly reduced migration and invasion below the basal levels in A549 cells.

\section{YXQ-EQ inhibits TGF- $\beta$ signaling in A549 cells}

Tumor metastasis is a major challenge in the management of NSCLC. EMT of cancer cells is associated with increased motility and a landmark of carcinoma progression during the metastatic phases. TGF- $\beta$ is known to induce EMT in cancer cells $[30,31]$. TGF- $\beta$ transduces signals via binding to the heteromeric TGF- $\beta$ receptor (TGF- $\beta$ R) composed of type I and type II serine/threonine kinases, which in turn phosphorylate and activate downstream effectors SMAD2 and SMAD3 [31, 32]. Compared to untreated cells, SMAD2/3 expression and phosphorylation were markedly reduced in YXQ-EQ treated A549 cells (Fig. 4A), indicating that YXQ-EQ might negatively regulate TGF- $\beta / T G F-\beta R$ signaling. To further address this notion, we examined the effect of YXQ-EQ on TGF- $\beta 1$ induced SMAD2/3 phosphorylation in A549 cells. As expected, TGF- $\beta 1$ treatment increased phosphorylation of SMAD 2 and SMAD3 in these cells (Fig. 4B). TGF- $\beta 1$ induced SMAD2/3 phosphorylation was abrogated by 5 min of YXQ-EQ pretreatment followed by the same TGF- $\beta 1$ incubation (Fig. 4B). As reported previously [33], A549 cells underwent EMT after TGF- $\beta 1$ treatment for $48 \mathrm{~h}$ (Fig. $4 \mathrm{C}$ and D). To examine the effect of YXQ-EQ on TGF- $\beta 1$ induced EMT, A549 cells were treated with YXQ-EQ for 5 min prior to incubation with TGF- $\beta 1$. It was observed that A549 cells had lost their intact morphology and died $48 \mathrm{~h}$ post YXQ-EQ treatment, regardless of treatment with TGF- $\beta 1$ (Fig. 4E and F).

\section{Discussion}

In the present study, we show that YXQ-EQ treatment exerted profound cytotoxic effect on lung cancer A549 cells and inhibited EGF/EGFR and TGF- $\beta 1 /$ SMAD signaling pathways that play an important role in lung cancer metastasis. These findings are in agreement 
Yan et al.: YXQ-EQ Induces Apoptosis and Inhibits Pro-Metastatic Pathways in NSCLC Cells

with previously reported potent cytotoxicity of YXQ-EQ toward cancer cells and inhibition of multiple signaling pathways by YXQ-EQ in cancer cells [7-11]. These studies together provide some important molecular and cellular insights into the clinically observed anticancer activities of YXQ-EQ.

EGFR is expressed in $60 \%$ of NSCLC and mutated in approximately $10-35 \%$ of NSCLC [25-27]. The EGF/EGFR signaling is involved in a wide variety of cellular events, including proliferation, migration, and invasion [34,35]. Growing evidence show that activation of AKT and ERK1/2 is critical for survival and proliferation driven by EGFR signals, either activated by EGFR ligands or activating EGFR mutations, in NSCLC $[28,29]$. EGFR tyrosine kinase inhibitors (TKIs) are effective in treatment of lung cancer with activating EGFR mutations and currently the standard treatment option for advanced NSCLC; however, often resistance to TKIs develops within months after the start of treatment $[34,36]$. TKIs alone have limited effect on NSCLC with wild type EGFR $[35,37]$ and dual inhibition of EGFR and AKT is required to induce apoptosis and inhibit growth of EGFR wild type NSCLC cells [38, 39]. A549 cells express wild type EGFR that is important for A549 cell growth [40]. Concomitant inhibition of AKT and ERK1/2 synergistically inhibits A549 cell growth and induces apoptosis in vitro and in vivo [24, 41, 42]. In agreement with these findings, YXQ-EQ induced apoptosis was associated with dual inhibition of AKT and ERK1/2 activation in A549 cells.

Lung cancer has a high potential for metastasis and this poses a challenge to lung cancer therapy. As reported previously [43, 44], EGFR activation with EGF enhanced A549 cell migration and invasion. AKT activation is required in EGF mediated lung cancer cell migration and invasion [43, 44]. Furthermore, ERK1/2 is also involved in A549 cell migration and invasion $[45,46]$. These findings suggest that inhibition of AKT and ERK1/2 activation may be at least partly involved in the mechanism of inhibition of EGF mediated A549 cell migration and invasion by $\mathrm{YXQ}-\mathrm{EQ}$.

TGF- $\beta$ is a pleiotropic cytokine known to drive cancer progression by multiple mechanisms including promotion of angiogenesis and metastasis, and suppression of antitumor immunity $[47,48]$. TGF- $\beta$ induced EMT increases the potential for tumor metastasis by enhancing motility and invasion of cancer cells $[30,49]$. TGF- $\beta$ induces EMT in cancer cells including A549 cells by activating SMAD2/3, AKT, and ERK1/2 [33, 50-52]. Inhibition of TGF- $\beta$ /SMAD signaling by YXQ-EQ reported here suggests that YXQ-EQ may also exert antitumor effects by inhibiting the pro-tumor activities of TGF- $\beta$.

It remains to be investigated how YXQ-EQ inhibits EGF/EGFR and TGF- $\beta$ /SMAD signaling. This may involve structural alterations of the receptors imposed by YXQ-EQ, since YXQ-EQ has been shown to influence the molecular structure of proteins and enzyme activity in previous studies [20-22]. The suppression of activation of AKT and ERK1/2 by YXQ-EQ may result from direct inhibition of the kinases themselves and/or indirectly from inhibition of upstream receptors or mediators. For example, YXQ-EQ may inhibit AKT activation via suppressing PI3K enzyme activity, shown in a previous study [22]. While more studies are needed to elucidate the mechanisms underlying YXQ-EQ's cytotoxic effect and inhibitory effect on EGF/EGFR and TGF- $\beta$ /SMAD signaling in A549 cells, findings presented here suggest that YXQ-EQ may have anti-NSCLC activity via inhibiting multiple signaling pathways important for NSCLC cell survival and metastasis.

\section{Acknowledgements}

This work was supported in part by Yan Xin Foundation.

\section{Disclosure Statement}

The authors declare to have no competing interests. 


\section{Cellular Physiology Cell Physiol Biochem 2018;49:911-919 \begin{tabular}{l|l|l} 
and Biochemistry 2018 The Author(s). Published by S. Karger AG, Basel \\
Publisnea onine: 5 september, 2018 www.karger.com/cpb
\end{tabular}}

Yan et al.: YXQ-EQ Induces Apoptosis and Inhibits Pro-Metastatic Pathways in NSCLC Cells

\section{References}

1 Jemal A, Bray F, Center MM, Ferlay J, Ward E, Forman D: Global cancer statistics. CA Cancer J Clin 2011;61:69-90.

-2 Siegel RL, Miller KD, Jemal A: Cancer statistics, 2015. CA Cancer J Clin 2015;65:5-29.

3 Singhal S, Miller D, Ramalingam S, Sun SY: Gene expression profiling of non-small cell lung cancer. Lung Cancer 2008; 60:313-324.

-4 Hanna N, Johnson D, Temin S, Baker S, Jr., Brahmer J, Ellis PM, Giaccone G, Hesketh PJ, Jaiyesimi I, Leighl NB, Riely GJ, Schiller JH, Schneider BJ, Smith TJ, Tashbar J, Biermann WA, Masters G: Systemic Therapy for Stage IV Non-Small-Cell Lung Cancer: American Society of Clinical Oncology Clinical Practice Guideline Update. J Clin Oncol 2017;35:3484-3515.

5 Karachaliou N, Gonzalez-Cao M, Sosa A, Berenguer J, Bracht JWP, Ito M, Rosell R: The combination of checkpoint immunotherapy and targeted therapy in cancer. Ann Transl Med 2017;5:388.

6 Yan X, Shen H, Zaharia M, Wang J, Wolf D, Li F, Lee GD, Cao W: Involvement of phosphatidylinositol 3-kinase and insulin-like growth factor-I in YXLST-mediated neuroprotection. Brain Res 2004;1006:198-206.

7 Yan X, Shen H, Jiang H, Zhang C, Hu D, Wang J, Wu X: External Qi of Yan Xin Qigong differentially regulates the Akt and extracellular signal-regulated kinase pathways and is cytotoxic to cancer cells but not to normal cells. Int J Biochem Cell Biol 2006;38:2102-2113.

8 Yan X, Shen H, Jiang H, Zhang C, Hu D, Wang J, Wu X: External Qi of Yan Xin Qigong induces G2/M arrest and apoptosis of androgen-independent prostate cancer cells by inhibiting Akt and NF-kB pathways. Mol Cell Biochem 2008;310:227-234.

-9 Yan X, Shen H, Jiang H, Hu D, Zhang C, Wang J, Wu X: External Qi of Yan Xin Qigong Induces apoptosis and inhibits migration and invasion of estrogen-independent breast cancer cells through suppression of Akt/ NF-kB signaling. Cell Physiol Biochem 2010;25:263-270.

10 Yan X, Li F, Dozmorov I, Frank MB, Dao M, Centola M, Cao W, Hu D: External Qi of Yan Xin Qigong induces cell death and gene expression alterations promoting apoptosis and inhibiting proliferation, migration and glucose metabolism in small-cell lung cancer cells. Mol Cell Biochem 2012;363:245-255.

11 Yan X, Shen H, Jiang H, Hu D, Wang J, Wu X: External Qi of Yan Xin Qigong inhibits activation of Akt, Erk1/2 and NF-kB and induces cell cycle arrest and apoptosis in colorectal cancer cells. Cell Physiol Biochem 2013;31:113-122.

12 Fong YH: Yan Xin Qigong informative product: Qi nutrition powder; in International Yan Xin Qigong Association (ed): Yan Xin Qigong Collectanea. Quebec, Les Editions LOTUS Publishers of Canada, 1997, vol. 6, pp 299-318.

13 Lu Z: Scientific Qigong exploration: the wonders and mysteries of Qi. Malvern, Amber Leaf Press, 1997.

14 Ming Z: The new frontiers of modern sciences: an introduction to Yan Xin Qigong. Beijing, Xinhua Press, 1988.

15 Wang R, Zhu R: Yan Xin Qigong nutrition powder: report of nine cases; in International Yan Xin Qigong Association (ed): Yan Xin Qigong Collectanea. Quebec, Les Editions LOTUS Publishers of Canada, 1997, vol. 1, pp 266-271.

16 Zhang ZW, Zhao JX, Zhang XR: Yan Xin Qigong nutrition powder: clinical report; in International Yan Xin Qigong Association (ed): Yan Xin Qigong Collectanea. Quebec, Les Editions LOTUS Publishers of Canada, 1997, vol. 1, pp 319-329.

17 Yan X, Zheng C, Zou G, Lu Z: Observations of the effects of external Qi on the ultraviolet absorption of nucleic acids. Chin J Nat 1988;11:647-649.

18 Yan X, Zhao N, Yin C, Lu Z: The effect of external Qi on liposome phase behavior. Chin J Nat 1988;11:572576.

19 Li S, Sun M, Dai Z, Zhang P, Meng G, Liu Z, Ma Q, Zhu Q, Wang Q, Zhang L, Shan L, Sun Y, Hu Y, Chen Y, Pang Y, Wang G, Hao X, Lu A, Fan X, Yan X: Experimental studies on the feasibility of improving industrial strains with external Qi treatment. Chin J Nat 1990;13:791-801.

20 Yan X, Lin H, Li H, Traynor-Kaplan A, Xia Z, Lu F, Fang Y, Dao M: Structural and property changes in certain materials influenced by the external Qi of Qigong. Mater Res Innov 1999;2:349-359.

21 Yan X, Lu F, Jiang H, Wu X, Cao W, Xia Z, Dao M, Lin H: Certain manifestation and effects of external Qi of Yan Xin life science and technology. J Sci Explor 2002;16:381-411. 


\section{Cellular Physiology Cell Physiol Biochem 2018;49:911-919 \begin{tabular}{l|l|l|l} 
DOI: 10.1159/000493223 & (c) 2018 The Author(s). Published by S. Karger AG, Basel
\end{tabular} and Biochemistry Publisned onine: s September, 2018 www.karger.com/cpb}

Yan et al.: YXQ-EQ Induces Apoptosis and Inhibits Pro-Metastatic Pathways in NSCLC

Cells

-22 Yan X, Xia ZQ, Shen H, Traynor-Kaplan A: External Qi of Yan Xin life science and technology can revive or suppress enzyme activity of phosphatidylinositol 3-kinase. Bull Sci Tech Soc 2002;22:403-406.

23 Xin Y, Fong YT, Wolf G, Wolf D, Cao W: Protective effect of XY99-5038 on hydrogen peroxide induced cell death in cultured retinal neurons. Life Sci 2001;69:289-299.

-24 Meng J, Dai B, Fang B, Bekele BN, Bornmann WG, Sun D, Peng Z, Herbst RS, Papadimitrakopoulou V, Minna JD, Peyton M, Roth JA: Combination treatment with MEK and AKT inhibitors is more effective than each drug alone in human non-small cell lung cancer in vitro and in vivo. PLoS One 2010;5:e14124.

-25 da Cunha Santos G, Shepherd FA, Tsao MS: EGFR mutations and lung cancer. Annu Rev Pathol 2011;6:4969.

-26 Siegelin MD, Borczuk AC: Epidermal growth factor receptor mutations in lung adenocarcinoma. Lab Invest 2014;94:129-137.

27 Sharma SV, Bell DW, Settleman J, Haber DA: Epidermal growth factor receptor mutations in lung cancer. Nat Rev Cancer 2007;7:169-181.

28 Sergina NV, Moasser MM: The HER family and cancer: emerging molecular mechanisms and therapeutic targets. Trends Mol Med 2007;13:527-534.

29 Carcereny E, Moran T, Capdevila L, Cros S, Vila L, de Los Llanos Gil M, Remon J, Rosell R: The epidermal growth factor receptor (EGRF) in lung cancer. Transl Respir Med 2015;3:1.

-30 Katsuno Y, Lamouille S, Derynck R: TGF-beta signaling and epithelial-mesenchymal transition in cancer progression. Curr Opin Oncol 2013;25:76-84.

31 Smith AL, Robin TP, Ford HL: Molecular pathways: targeting the TGF-beta pathway for cancer therapy. Clin Cancer Res 2012;18:4514-4521.

32 Heldin CH, Miyazono K, ten Dijke P: TGF-beta signalling from cell membrane to nucleus through SMAD proteins. Nature 1997;390:465-471.

-33 Choi JH, Hwang YP, Kim HG, Khanal T, Do MT, Jin SW, Han HJ, Lee HS, Lee YC, Chung YC, Jeong TC, Jeong HG: Saponins from the roots of Platycodon grandiflorum suppresses TGFbeta1-induced epithelialmesenchymal transition via repression of PI3K/Akt, ERK1/2 and Smad2/3 pathway in human lung carcinoma A549 cells. Nutr Cancer 2014;66:140-151.

-34 Oxnard GR, Arcila ME, Chmielecki J, Ladanyi M, Miller VA, Pao W: New strategies in overcoming acquired resistance to epidermal growth factor receptor tyrosine kinase inhibitors in lung cancer. Clin Cancer Res 2011;17:5530-5537.

35 Janmaat ML, Kruyt FA, Rodriguez JA, Giaccone G: Response to epidermal growth factor receptor inhibitors in non-small cell lung cancer cells: limited antiproliferative effects and absence of apoptosis associated with persistent activity of extracellular signal-regulated kinase or Akt kinase pathways. Clin Cancer Res 2003;9:2316-2326.

-36 Hrustanovic G, Lee BJ, Bivona TG: Mechanisms of resistance to EGFR targeted therapies. Cancer Biol Ther 2013;14:304-314.

-37 Janmaat ML, Rodriguez JA, Gallegos-Ruiz M, Kruyt FA, Giaccone G: Enhanced cytotoxicity induced by gefitinib and specific inhibitors of the Ras or phosphatidyl inositol-3 kinase pathways in non-small cell lung cancer cells. Int J Cancer 2006;118:209-214.

-38 Hirai H, Sootome H, Nakatsuru Y, Miyama K, Taguchi S, Tsujioka K, Ueno Y, Hatch H, Majumder PK, Pan BS, Kotani H: MK-2206, an allosteric Akt inhibitor, enhances antitumor efficacy by standard chemotherapeutic agents or molecular targeted drugs in vitro and in vivo. Mol Cancer Ther 2010;9:1956-1967.

-39 Puglisi M, Thavasu P, Stewart A, de Bono JS, O’Brien ME, Popat S, Bhosle J, Banerji U: AKT inhibition synergistically enhances growth-inhibitory effects of gefitinib and increases apoptosis in non-small cell lung cancer cell lines. Lung Cancer 2014;85:141-146.

-40 Yamanaka S, Gu Z, Sato M, Fujisaki R, Inomata K, Sakurada A, Inoue A, Nukiwa T, Kondo T, Horii A: siRNA targeting against EGFR, a promising candidate for a novel therapeutic application to lung adenocarcinoma. Pathobiology 2008;75:2-8.

41 Chen J, Bi H, Hou J, Zhang X, Zhang C, Yue L, Wen X, Liu D, Shi H, Yuan J, Liu J, Liu B: Atorvastatin overcomes gefitinib resistance in KRAS mutant human non-small cell lung carcinoma cells. Cell Death Dis 2013;4:e814.

42 Zhang J, Hong Y, Shen J: Combination treatment with perifosine and MEK-162 demonstrates synergism against lung cancer cells in vitro and in vivo. Tumour Biol 2015;36:5699-5706. 


\section{Cellular Physiology Cell Physiol Biochem 2018:49:911-919

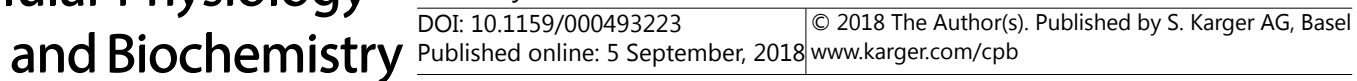 \\ Yan et al.: YXQ-EQ Induces Apoptosis and Inhibits Pro-Metastatic Pathways in NSCLC \\ Cells}

43 Hauck CR, Sieg DJ, Hsia DA, Loftus JC, Gaarde WA, Monia BP, Schlaepfer DD: Inhibition of focal adhesion kinase expression or activity disrupts epidermal growth factor-stimulated signaling promoting the migration of invasive human carcinoma cells. Cancer Res 2001;61:7079-7090.

-44 Whitsett TG, Cheng E, Inge L, Asrani K, Jameson NM, Hostetter G, Weiss GJ, Kingsley CB, Loftus JC, Bremner R, Tran NL, Winkles JA: Elevated expression of Fn14 in non-small cell lung cancer correlates with activated EGFR and promotes tumor cell migration and invasion. Am J Pathol 2012;181:111-120.

-45 Shih YW, Shieh JM, Wu PF, Lee YC, Chen YZ, Chiang TA: Alpha-tomatine inactivates PI3K/Akt and ERK signaling pathways in human lung adenocarcinoma A549 cells: effect on metastasis. Food Chem Toxicol 2009;47:1985-1995.

-46 Lee YC, Lin HH, Hsu CH, Wang CJ, Chiang TA, Chen JH: Inhibitory effects of andrographolide on migration and invasion in human non-small cell lung cancer A549 cells via down-regulation of PI3K/Akt signaling pathway. Eur J Pharmacol 2010;632:23-32.

-47 Ikushima H, Miyazono K: TGFbeta signalling: a complex web in cancer progression. Nat Rev Cancer 2010;10:415-424.

48 Massague J: TGFbeta in Cancer. Cell 2008;134:215-230.

49 Yang J, Weinberg RA: Epithelial-mesenchymal transition: at the crossroads of development and tumor metastasis. Dev Cell 2008;14:818-829.

50 Chen KC, Chen CY, Lin CR, Yang TY, Chen TH, Wu LC, Wu CC: Luteolin attenuates TGF-beta1-induced epithelial-mesenchymal transition of lung cancer cells by interfering in the PI3K/Akt-NF-kappaB-Snail pathway. Life Sci 2013;93:924-933.

51 Julien S, Puig I, Caretti E, Bonaventure J, Nelles L, van Roy F, Dargemont C, de Herreros AG, Bellacosa A, Larue L: Activation of NF-kappaB by Akt upregulates Snail expression and induces epithelium mesenchyme transition. Oncogene 2007;26:7445-7456.

\$52 Liu LC, Tsao TC, Hsu SR, Wang HC, Tsai TC, Kao JY, Way TD: EGCG inhibits transforming growth factor-betamediated epithelial-to-mesenchymal transition via the inhibition of Smad2 and Erk1/2 signaling pathways in nonsmall cell lung cancer cells. J Agric Food Chem 2012;60:9863-9873. 